\title{
THE INFLUENCE OF IDEAS OF SURREALISM IN FASHION DESIGN
}

\section{Marija Kertakova}

Faculty of Technology, University Goce Delcev Stip, Krste Misirkov b.b., Republic North of Macedonia

* e-mail: marija.kertakova@ugd.edu.mk
Stručni rad

UDC: 7.038:391.

doi: $10.5937 /$ tekstind1904036K

\begin{abstract}
The efforts of fashion modellers, designers, and manufacturers to produce clothing for the modern man have led to a huge variety of stylistic tendencies when designing the clothes. However, they are based on both archetypal principles related to the immutability of the physical parameters of the human body and its psycho-physical needs, related to the design, production, sale and use of clothing. The artist and fashion designer, as well as all the other figures in the consumer-creator chain, are rethinking their role. The value of clothing as a work of art comes to the fore, but it is also very important for the modern man to be significative with the help of clothes which the wearer wears as information on his cultural and philosophical doctrine. The relationship between art and costume is atypical for an average person, but only for one who has a particularly thorough knowledge of both objects and understands that fashion is part of applied art (which means that fashion is on its own way very individual specific kind of art). In connection with the above works, the object of my research is the process of emulation, processing and applying the artistic experience of XX century painting - i.e. Surrealism in the costume of XX and XXI centuries. How was the transfer of the artistic elements of painting done, their adaptation and modification in some of the most emblematic models of world-famous designers working in the XX and XXI centuries.
\end{abstract}

Keywords: artist, fashion designer, fashion as artwork, painting-costume relationship, surrealism.

\section{UTICAJ IDEJA NADREALIZMA U MODNOM DIZAJNU}

Apstrakt: Napori modnih modelara, dizajnera i proizvođača da proizvedu odeću za modernog čoveka doveli su do ogromne raznolikosti stilskih tendencija prilikom dizajniranja odeće. Međutim, zasnivaju se na arhetipskim principima koji se odnose na nepromenjivost fizičkih parametara ljudskog tela i njegovih psihofizičkih potreba, vezanih za dizajn, proizvodnju, prodaju i upotrebu odeće. Umetnik i modni dizajner, kao i sve ostale ličnosti u lancu potrošača-kreatora, preispituju svoju ulogu. Vrednost odeće kao umetničkog dela dolazi do izražaja, ali takođe je veoma važno da moderni čovek bude značajan uz pomoć odeće koju nosilac nosi kao informaciju o svojoj kulturnoj i filozofskoj doktrini. Odnos između umetnosti i kostima nije atipičan za prosečnog čoveka, ali samo za onog koji ima posebno temeljno znanje o oba predmeta i razume da je moda deo primenjene umetnosti (što znači da je moda na svoj način - vrlo individualna specifična vrsta umetnosti). $U$ vezi sa gore navedenim radovima, predmet mog istraživanja je proces oponašanja, obrade i primene umetničkog iskustva slikarstva XX veka-tj. Nadrealizam u nošnji XX i XXI veka. Kako je izvršen prenos umetničkih elemenata slikarstva, njihova adaptacija i modifikacije u nekim od najizrazitijih modela svetski poznatih dizajnera koji su radili u XXIXXI veku.

Ključne reči: umetnik, modni dizajner, moda kao umetničko delo, veza umetnosti i kostima, nadrealizam.

\section{INTRODUCTION}

In the context of my article on the implication of elements of the art - surrealism in the fashion trends of the $X X$ and $X X I$ centuries, first of all I remind on Ambroaz Beers's [1] statement about the fashion „A despot to whom clever people laugh, but to whom they obey". And it seems to me that this subordination (among other things) underlies the industrial production of fashionable clothes today, as well as the transfer of art from the twentieth into the fashion of the XX and XXI centuries. 
The French philosopher Pierre Boast admits that "many women died as martyrs in a fashion that forced them to endure lethargy as a victim of nudity" [2]. This bright and aphoristic thought very well illustrates the relevance and the influence of art on fashion. Not only does it have deep historical roots, it is not only a plastic or aesthetic phenomenon, it is also a phenomenon deeply related to human health. With this example, I would like to emphasize that the transfer of art in fashionable clothes is of significant meaning to man today. This is important for researchers, since many of the twentieth century fashion creators have drawn in full handfuls of artists of generations long gone.

The topicality of the question is that the change in the general artistic style of the different epochs is always connected with great ideological social changes. Whether these changes occur over a relatively long period or for a relatively short time. The actuality of the case is that the sources of inspiration of the creators of today's fashion brands or fashion lines are sought in closer or further historical horizons, but fashion never returns as something stagnant. On the contrary, the fact that famous fashion designers are inspired by the "achievements" of the art of long (or not so long) gone eras is acknowledged by the researchers, but the logic of the appearance of new shapes and silhouettes is different, not as it was in the process of their original nascency. The urgency of a thorough study of the development and alteration of the main forms of art in the twentieth century and their implications in the fashion of the twentieth and twenty-first centuries, however, manifest themselves in differences of design and decorative solutions, in the use of materials and their color combinations, as well as the combination of different in composition and structure fabrics used in sewing clothes are characteristic features of art and culture, manifested in the general lifestyle of society, affecting the life of each member. The relevance of the topic of this article is also related to the fact that I strive to explore and discover the specific intrinsic links between the art of painting, the aesthetic ideals of beauty and the shaping of fashion trends.

The overall purpose of this article is to explore the transfer of achievements, knowledge, skills and habits of the material culture and art of the twentieth century (in this case surrealism); how they were reflected in the costume of that time and its influence on contemporary fashion. In formulating the thesis and its research, I was based on the "convention", which was accepted by designers and artists that the costume was perceived as a work of art. The protoform of this conception was first formulated in the sixteenth century by the Venetian Cesare Vechelio [3], who elevated the status of the costume to a work of art. This of course is true, although from today's perspective is incomplete. In addition to artistry, the costume has utilitarian qualities and this cannot be completely ignored. That is why my other aim is to explore different
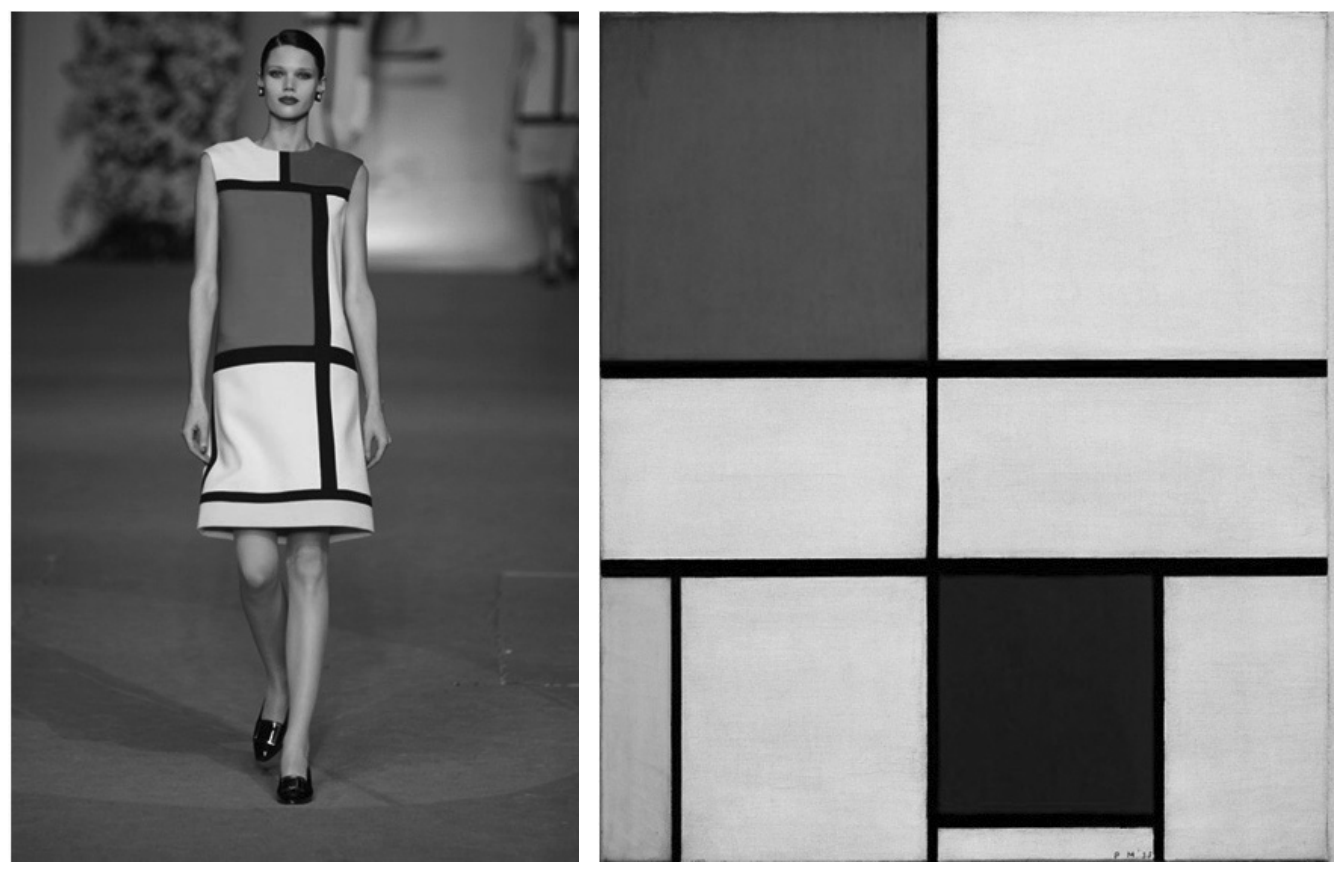

Figure 1: These two images show an example of an intraspecific transfer of how a painter's work (Right Part: Pete Mondrian Scoreboard II, 1921-25, oil on canvas, $74.9 \times 61.5 \mathrm{~cm}$, Zurich, private ownership) affects the creativity of (Left Part - Day Dress by Yves Saint Laurent Collection) the fashion designer 
aspects of surrealistic painting as a work of art that not only embodies the ideals of a bygone age, but also concentrates some of its achievements. In this connection, the main task in my work is formulated as an analysis of different compositions as artworks and their analogies that we find in specific fashion designs from the twentieth and twenty-first centuries.

In connection with the above facts, the object of my research is the process of borrowing, processing and applying the artistic experience embodied in the costume of the twentieth and twenty-first century. The subject of the study in this article is the painting in the XX century - i.e. surrealism - its design features and artistic qualities, which makes it an object and model for transformation in the fashion of the $X X$ and XXI centuries.

The basis of my theoretical reasoning underlies comparative test method. It involves studying and comparing the art of the surrealists - both in individual directions and in its entirety - with specimens of the twentieth and twenty-first century fashion.

My goal was to study the phenomenon of following the internal logic of the transfer of artistic (material and spiritual) values during the study period. The text seeks to organize and show the different ways and levels at which the implication of surrealism in contemporary fashion manifests itself.

\section{SURREALISM}

According to Wikipedia - "Surrealism is a cultural movement that started in 1917 and is best known for its visual artworks and writings. Artists painted unnerving, illogical scenes, sometimes with photographic precision, creating strange creatures from everyday objects, and developing painting techniques that allowed the unconscious to express itself. Its aim was, according to Breton, to "resolve the previously contradictory conditions of dream and reality into an absolute reality, a super-reality", or surreality".

In fact, surrealism resurrects the superior qualities of the irrational, unconscious mind. Its's goal was to liberate human mind from the oppressive boundaries of rationalism. It was strongly influenced by the psychoanalytical writings of Sigmund Freud. Its members believed in the idea that the unconscious mind which produced dreams was the source of artistic creativity. The main idea was to achieve liberation of the mind, which on its own hand gave the Surrealists the means to produce unconscious artwork. Of course this movement is completely in line with the massively spread great depression in the 1930s - which once again proves that imaginative movements always show in time when socio-cultural repression appears and that they are kind of way to escape the existing reality.

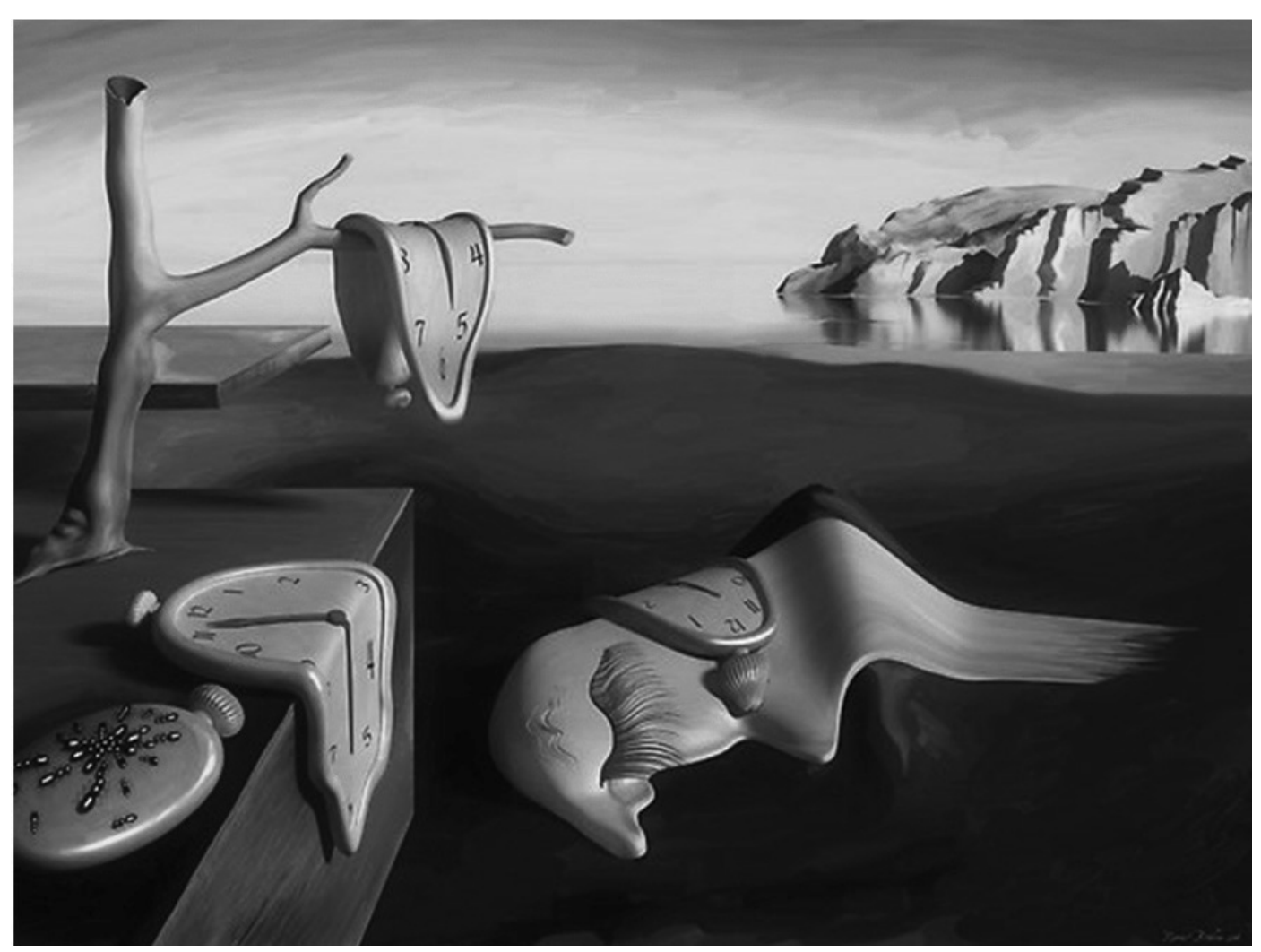

Figure 2: Salvador Dali, The Persistence of Memory, 1931. 


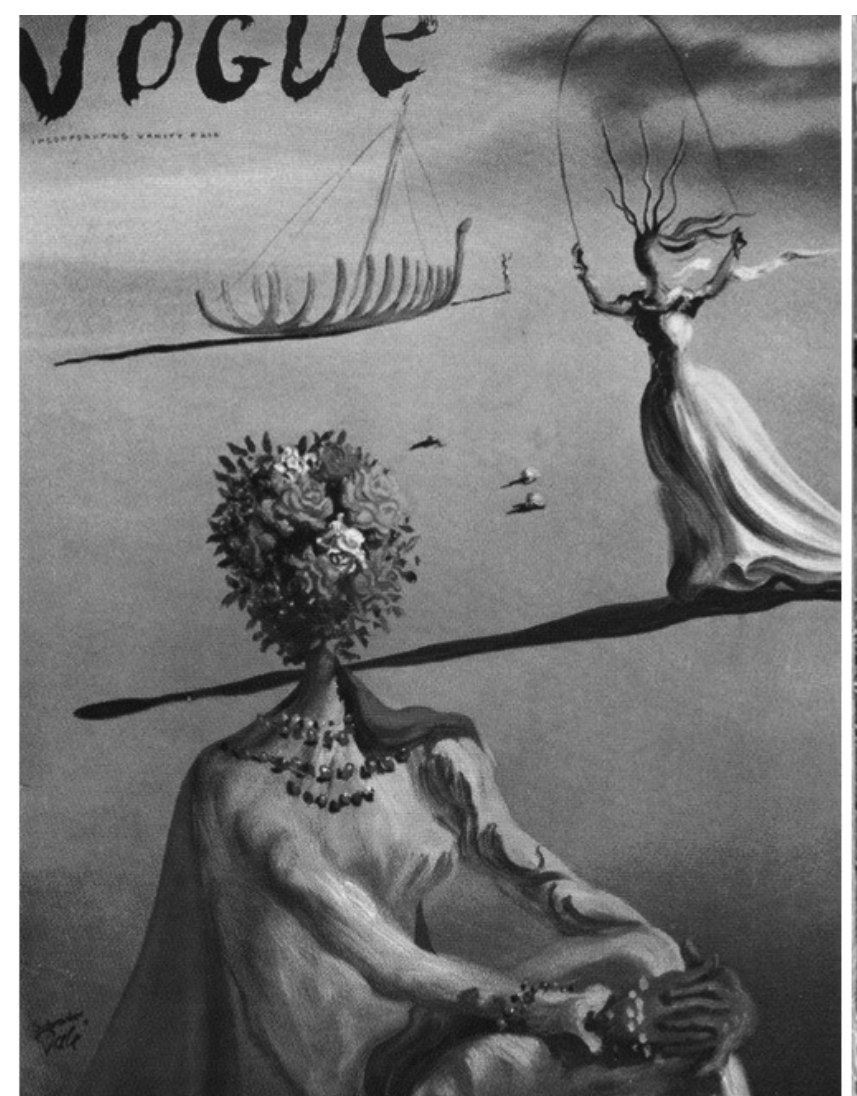

Figure 3: Salvador Dali for VOGUE

Decembe Cover 1938

\section{IMPLICATION OF SURREALISM INTO XX CENTURY FASHION}

When talking about the transfer of ideas from painting into the field of fashion, in first line we must mention the successes of Elsa Skiaparelli, who is the first woman to skillfully apply this transfer of ideas from classical art to fashion. The paradox is that not only does Skiaparelli discover the borrowing from surrealism, but she practically shatters the topic. She is by far the most dedicated person to this idea, who has devoted her energies to finding the solution to the transfer of ideas from various pictorial practices in fashion, using the strategy of surrealism in solving the "line-volume" dilemma. Other post-war fashion masters, such as Yves Saint Laurent, Terry Mugler, Christian Lacroix and Jean-Paul Gaultier, also offer wonderful solutions to the line-volume dilemma, partly inspired by the achievements of their contemporary artists.

The foundations of this "visual conflict" lie in the fact that the constant elucidation of the relationships that arise between real objects (including those that are the work of fashion design) and their life in our minds is something that is definitely once and for all. The costumes made by the designer are real, with a

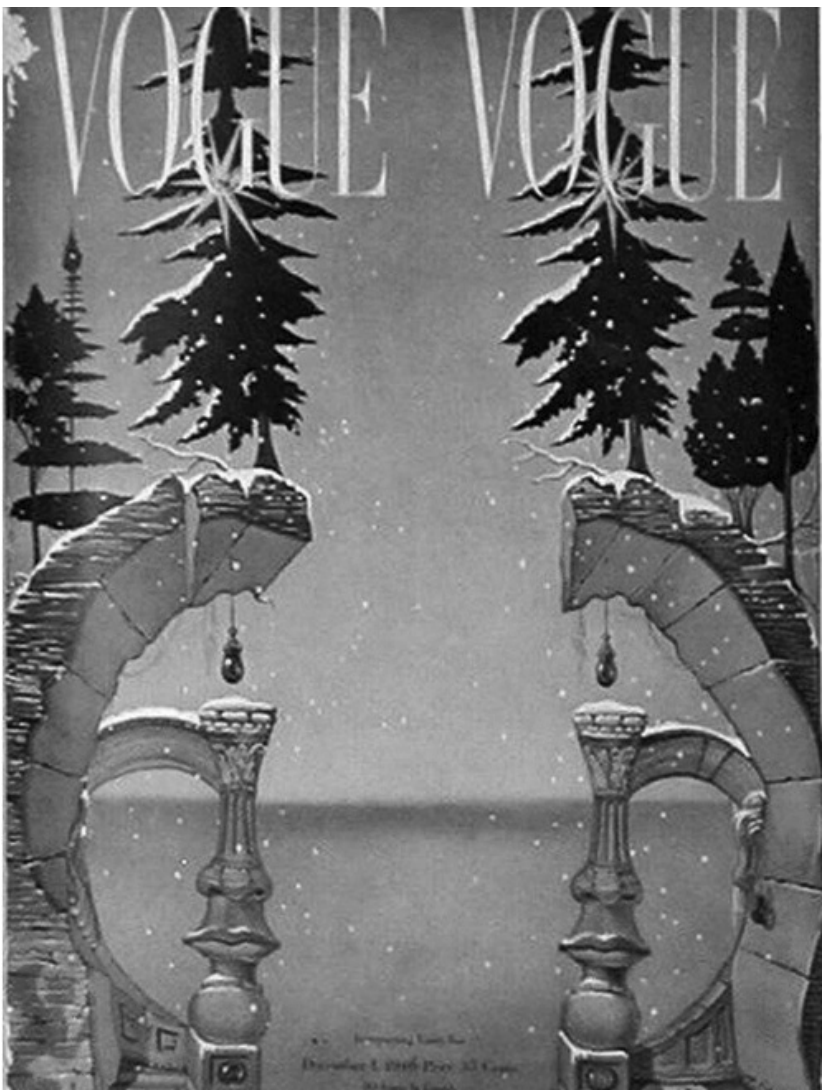

Figure 4: Salvador Dali for VOGUE Decembe Cover 1946

utilitarian purpose. Therefore, the illusion of the object is created, that is, it's ideal reflection, which is also loaded with additional meanings, to which the consciousness gives a mysterious meaning, making them mythologists, i.e. essential parts of the untold story, which is also the main feature of the artwork. However, surrealism does not have as much influence on fashion as it seems at first glance. The visual paradoxes of this time, although met with interest in painting, are not entering nor so quickly nor so widely into fashion. Designers are likely to fear that the successes of surrealist artists, who were on the crest of the wave at the time, will eclipse the successes of the artists themselves. The visual similarity carries not only creative but also legal dangers with regard to copyright. Indeed, the correct decision here is to use the artist's name rather than the motives underlying his particular painting. The principle is to use the artist's authority, name and abilities as a brand to create a separate item - a fabric cloth or a perfume bottle, rather than becoming a "co-author" of the design of the garment.

Creating his own collection of clothes for a certain fashion season, the fashion designer relies not on his specific buyer, unlike his colleagues of the last cen- 


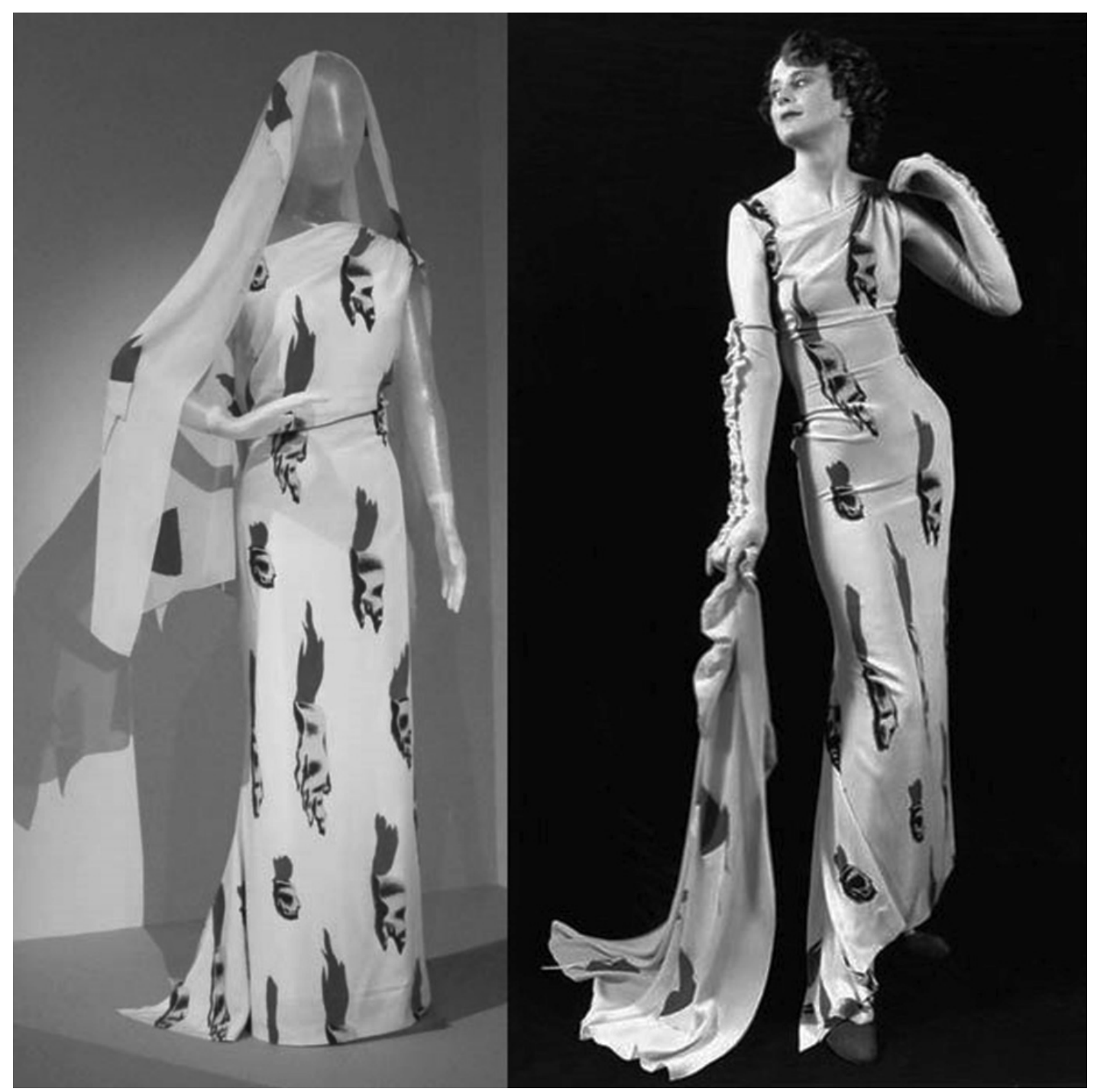

Figure 5: Skiaparelli dress with fabric made by Salvador Dali

tury, but has in front of him a collective, generalized image that, according to philosophers, "captures" all individual consumers. In an imperative way, the designer proclaims this image as conforming to the ideal (designing the ideal in itself), or at least intimately approaching it. This image necessarily carries the features of its time and is primary for the artist, but for the designer using the artistic strategy is secondary. For example, for surrealist artists, the search for the ideal woman was doomed to failure, since the ideal exists only in their imagination, but not in the reality that surrounds them.

Fictional, ie existing only in their minds, a woman cannot appear to man in his real life (according to them). Hence the obsessive interest of surrealist designers in the female body as an independent object, moreover, as a self-sufficient entity. A striking example of this is the "Shocking" perfume bottle (Figure 6
- left), shaped like a women's torso, similar to a sewing dummy, which Elsa Skiaparelli made back in 1938, and after more than 50 years, Jean Paul proposes his designs for a similar product that resembles a female body wrapped in a pink satin corset and emphasizing its insignificance by placing it in a tin can (Figure 6 - right). By abstracting from the body of the ideal woman, the surrealists show interest and focus their attention on the individual parts of the face, while becoming more ornamental and striving to lose the relationship between line and volume (at least optically). This is very clear in Yves Saint Laurent in his Summer, 1966 (Figure 7) and Summer 1971 (Figure 8) collections, as well as in Hubert de Givenchy in his jackets in the 1979 collection (Figure 9). "What do I want to do? Shock people and force them to think!" - stated Yves Saint Laurent in the March 1971 issue of Vogue Paris. 

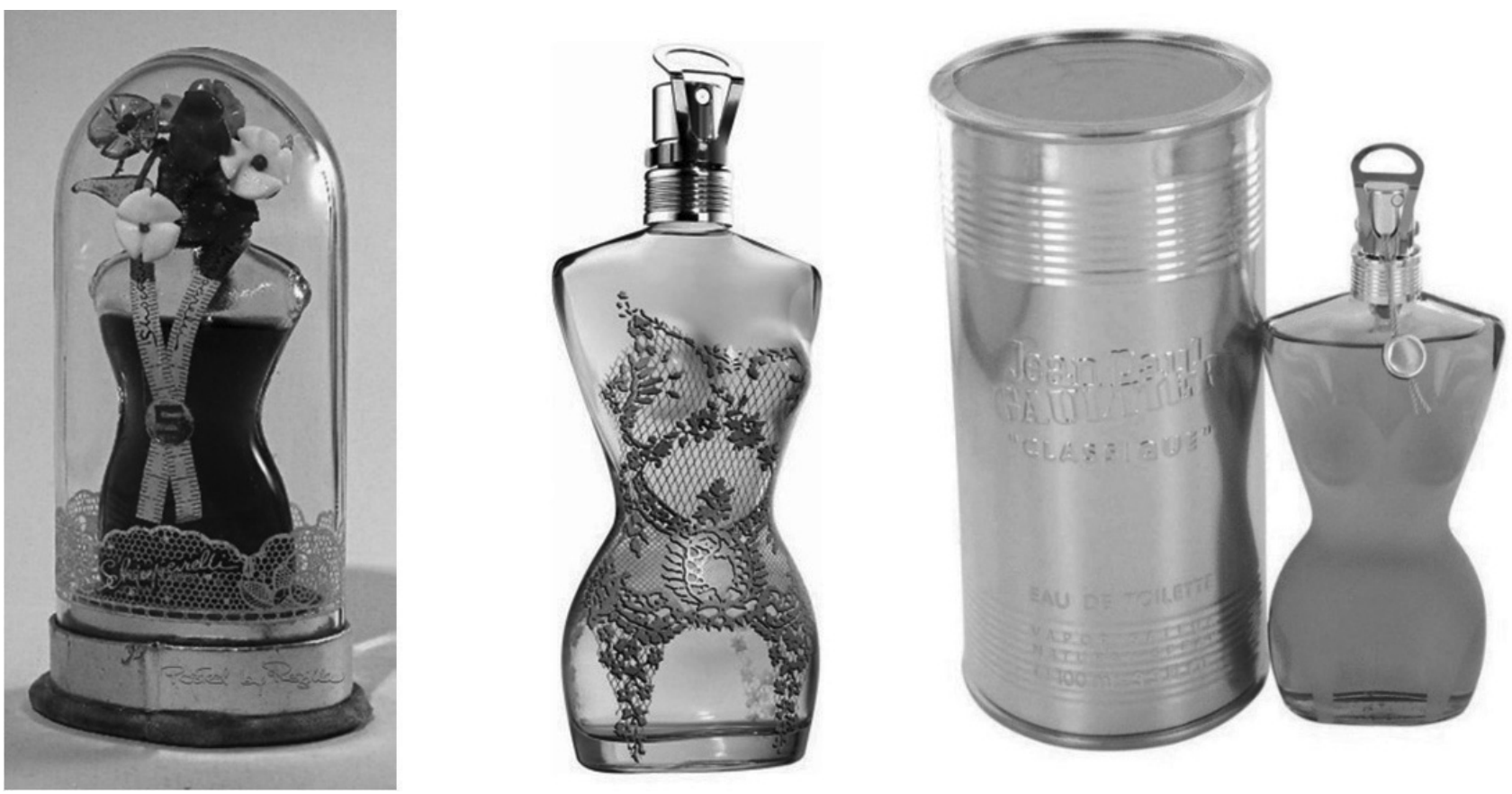

Figure 6: Elsa Schiaparelli (left) \& Jean-Paul Gaultier (right)
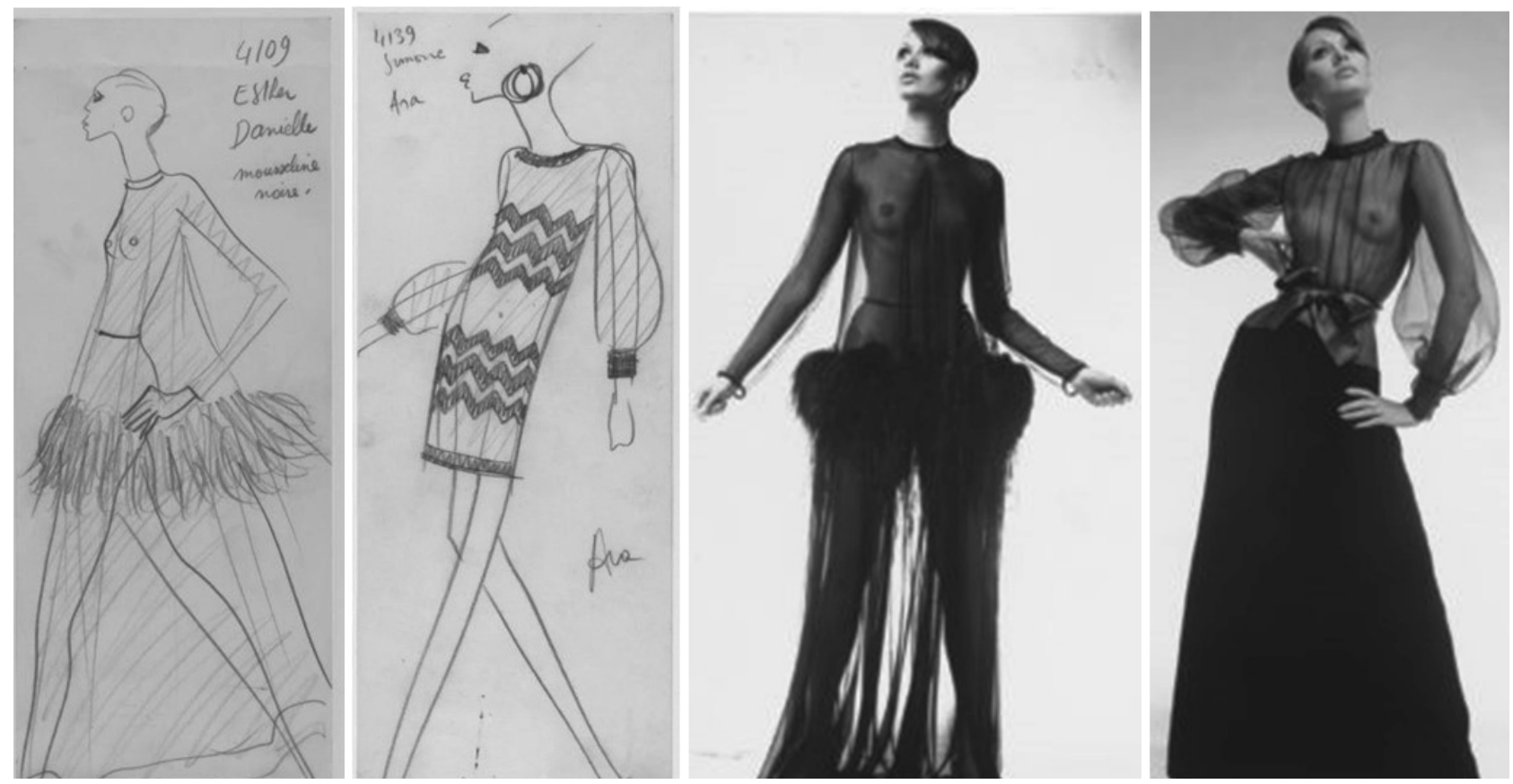

Figure 7: „Nothing is more beautiful than a naked body" - Yves Saint Laurent, Summer, 1966

The words of Rene Margit that "the garment conceals eroticism by living on the body of its owner and feeding on the memories of it" [4], seems to be the theoretical basis from which the dress-sculpture of Yves Saint Laurent appeared, which makes a metallic cast of busts of the dress, presenting fully alive anatomical shapes in his 1969/70 collection (Figure 10). We see Jean-Paul Gauthier taking a similar approach, which shows women's suits with cone-shaped busts, but this is not the only form that can be associated with a woman's body.
The strategy of the female body to be metaphorized by a stringed musical instrument (e.g. cello, mandolin, violin, and their soft curves not only resembling shoulder roundness, waist flexibility and rounded thighs, but also disobedience to the spirit) are demonstrated in fashion collection by Lagerfeld commissioned by Chloe in 1983. This experience was also used by Christian Lacroix in his fashion collection, presented two years later - in 1985.

Karl Lagerfeld, Chloé dress, Fall/Winter 1983, Paris. A showerhead and spurting water are depicted with 


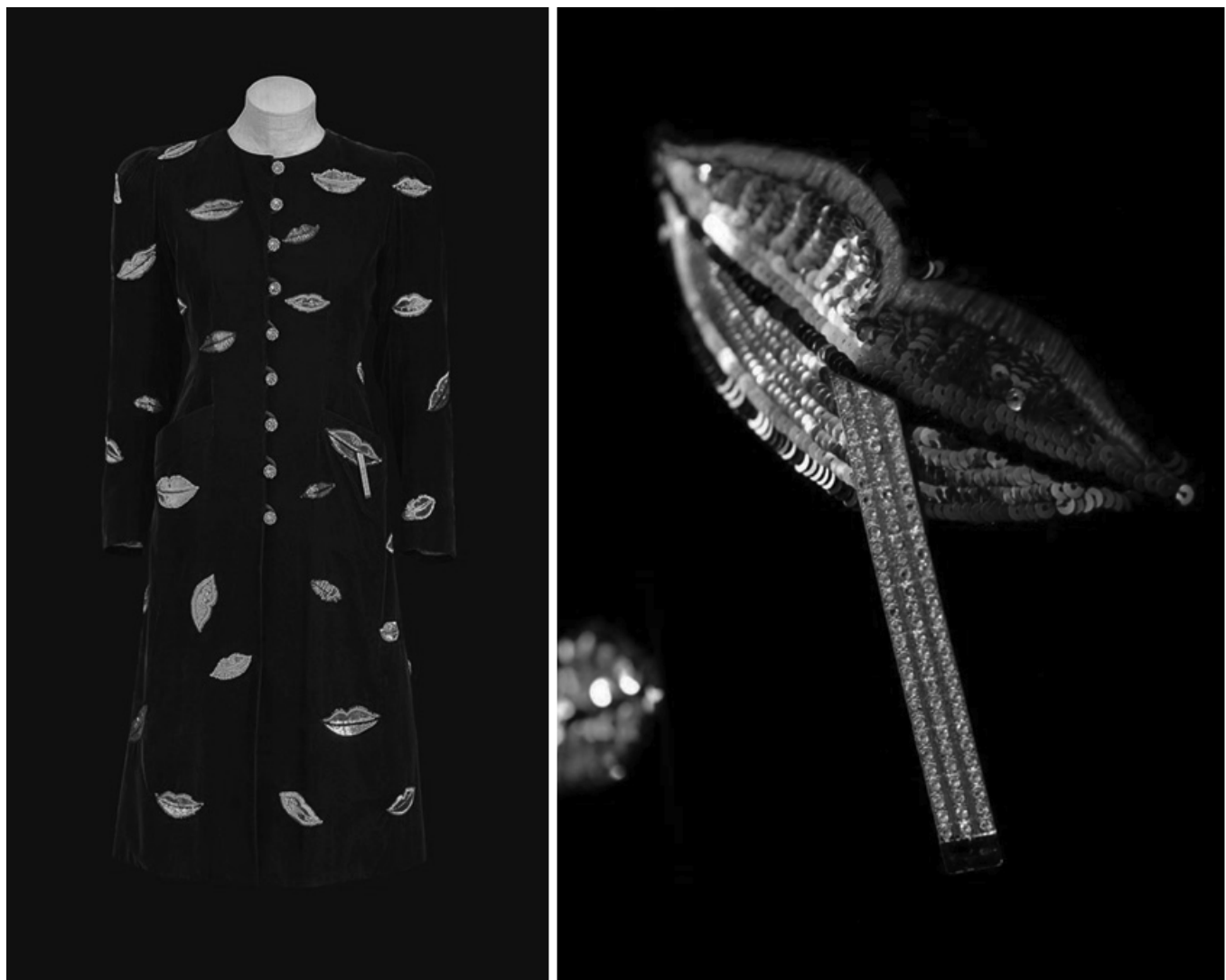

Figure 8: YSL: Lips motif coat, haute couture Spring/Summer 1971 collection with detail

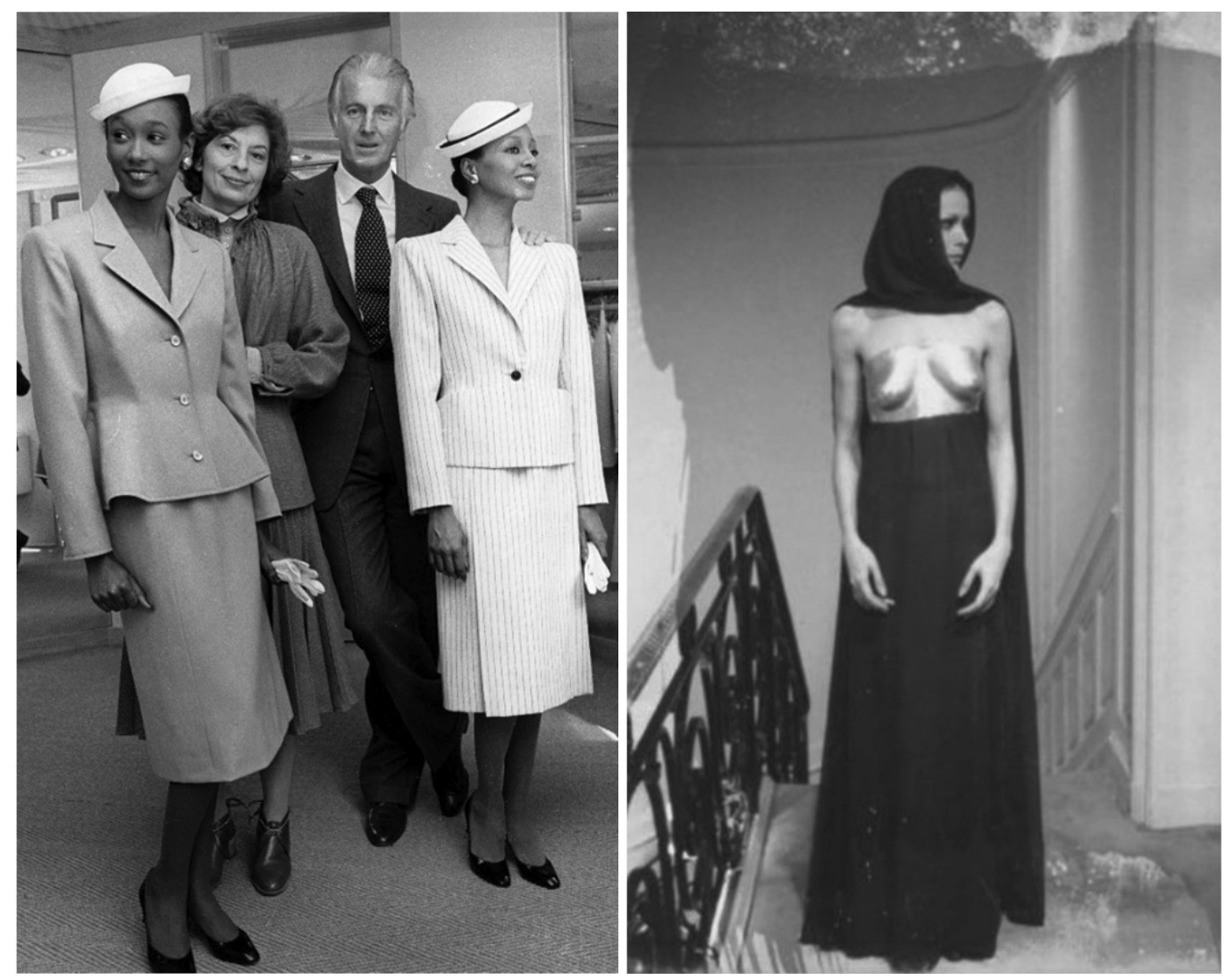

Figure 9: Hubert de Givenchy in New York promoting his latest offerings. Here he is with models in elegant nipped-waist suits in March 1979, unveiling looks from his fall/winter collection (left)

Figure 10: Yves Saint Laurent haute couture fall/winter 1969/70 (right) 
rhinestone embroidery on the front of the dress. The shower hose continues to the back of the dress and then entwines the left sleeve. This garment conveys the sense of humor and play typical for the creative designer.

The music, presented not only as a tool but also as a music manuscript, also inspired Serge Lutens to use in his advertising campaigns in 1979 models (Figure 13) who wear hats made of open musical notebooks and their earrings were shaped like a "treble clef".

The connection between the notions of beauty embodied in the ideal, their partial fulfillment in the real female body and its homologues in other natural forms, prompts Terry Mugler, who draws on Salvador Dali's statements about the creative power of dreams, to represent the woman once as an exquisite bird - Eagle Dress (1986) and Bird Dresses (1982); once as brilliant with its silver-gray flakes in Sardine Dress (1983); once as something like a delicate flower with its dress-begonias in his collections from 1981-82; moreover, this is earlier made by Yves Saint Laurent, who offers a wedding dress-bouquet in his fashion collection in 1980.
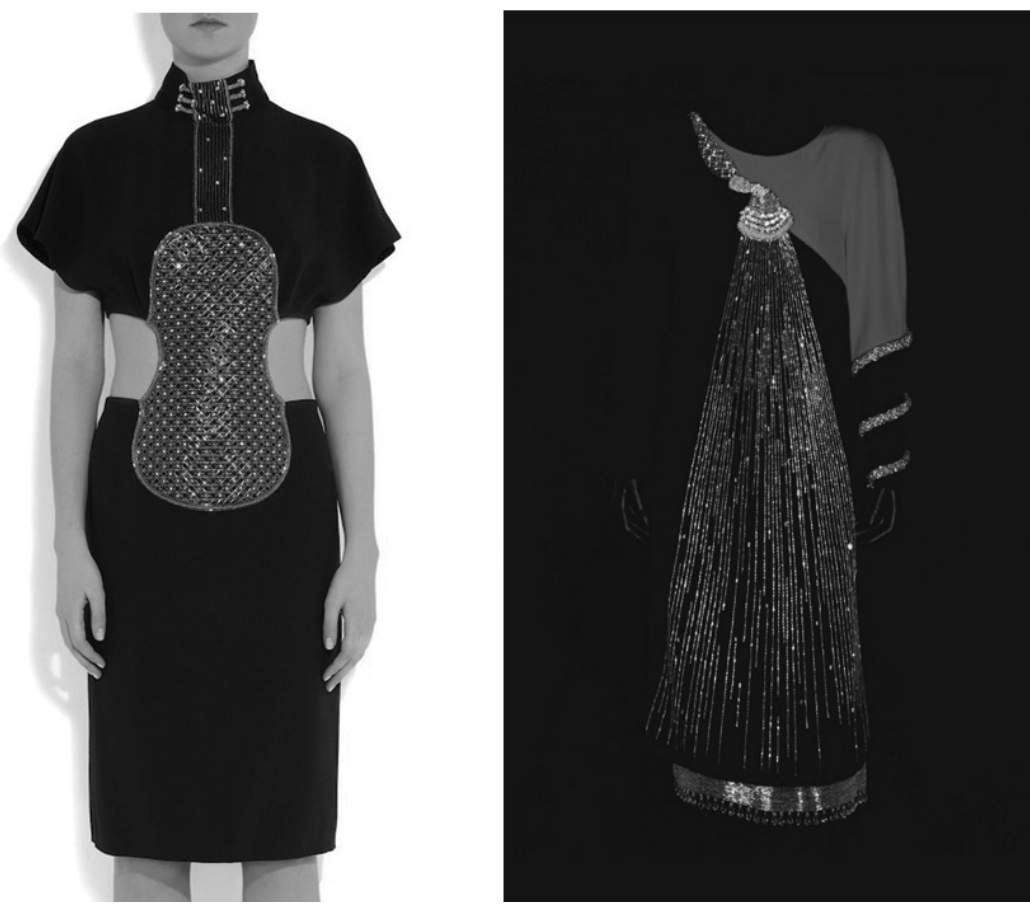

Figure 11: Karl Lagerfeld for Chloé - Beaded crepe Violin dress, 1983

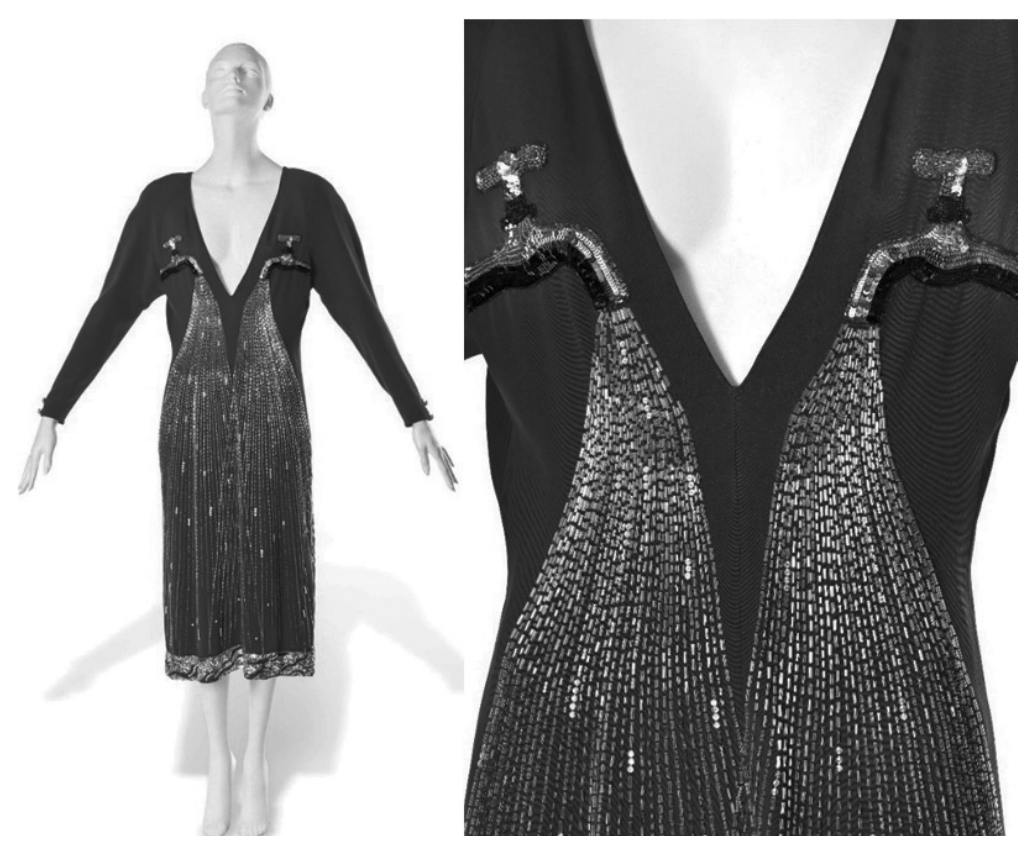

Figure 12: Karl Lagerfeld for Chloe, Royal Blue Satin Dress fall/ winter 1983

The low V-neck bodice embroidered with tap motifs in beads and silver sequins, with diamanté button fastening to the back, the sleeves long, embellished with diamanté buttons at the wrists
Another successful strategy to solve the line or volume dilemma is Christian Dior. What is special here is that the volume is present, its surrounding surface is linearized, and this linearity is enhanced to resemble a separate letter from the Latin al phabet. His first attempt was in 1954 (Figure 15), when he introduced the fashion for wearing men's suits, calling his collection „H-shaped 


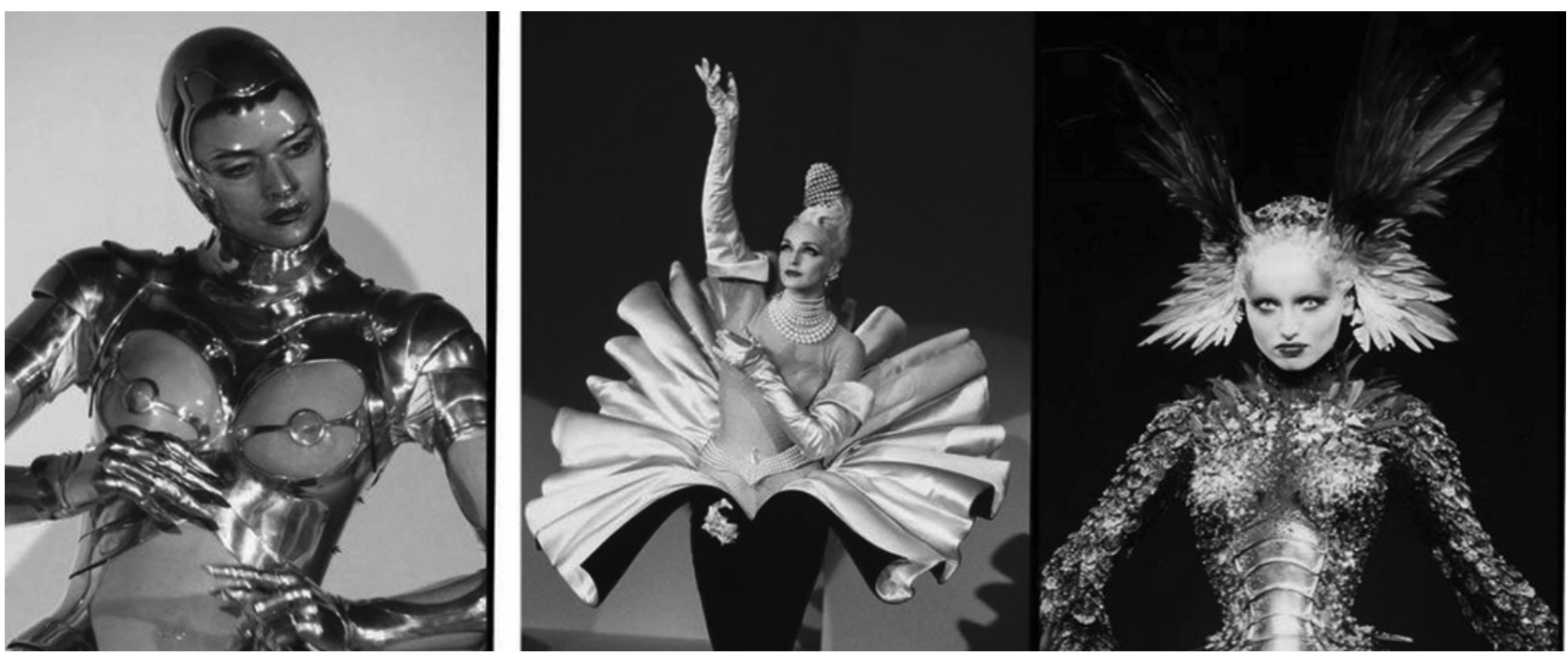

Figure 14: Terry Mugler The man who defined 1980s fashion

silhouettes". The implementation is a coat of white fine flax, broad and dialed with soft pleats, such as H-silhouette is particularly suitable for evening wear. This idea was realized by developing a silhouette with the letter $A$ and a silhouette with the letter $Y$ with large $V$-shaped collars and huge quadrilateral scarves. O'Hara gives the following summarizing assessment of his work: "The undeniable elegance and sculptural sophistication of his outfits have been a strong influence on designers and women around the world for a decade" [5]. The high fashion of the twentieth century is firmly based on the achievements of the two previous ones - the eighteenth and nineteenth centuries.

The implication of these two centuries can be summed up briefly as follows: „pomp and splendor of color, cloth and volume". As one of the masters of implementing such a principle in the twentieth century, we can point to Christian Dior and his role will become even clearer when comparing it to Poaret and Skiaparelli. Although all three authors are eclectic in a sense, each is "eclectic" in its own right. I would like to emphasize that here I use the word eclecticism in a positive sense.

On the one hand, the designers of the twentieth century cannot be completely different from their counterparts who worked before them, and on the other, the fashion of the twentieth century as an expression of the social ideal rests on the superior achievements of its predecessors - this is also its great merit - to use achievements by developing and enriching the best of them.

In my opinion, Dior's creative and commercial secret lies in his words: "A woman becomes most attractive at the age of 35 when her first youth passes, her mind blossoms and she needs chic" [6]. Indeed, if we analyze the innumerable defiles and collections he presents to them, despite their vast diversity over the years, it will be seen that they are united by two guiding thoughts - about a woman who not only can, but also needs to be dressed accord-

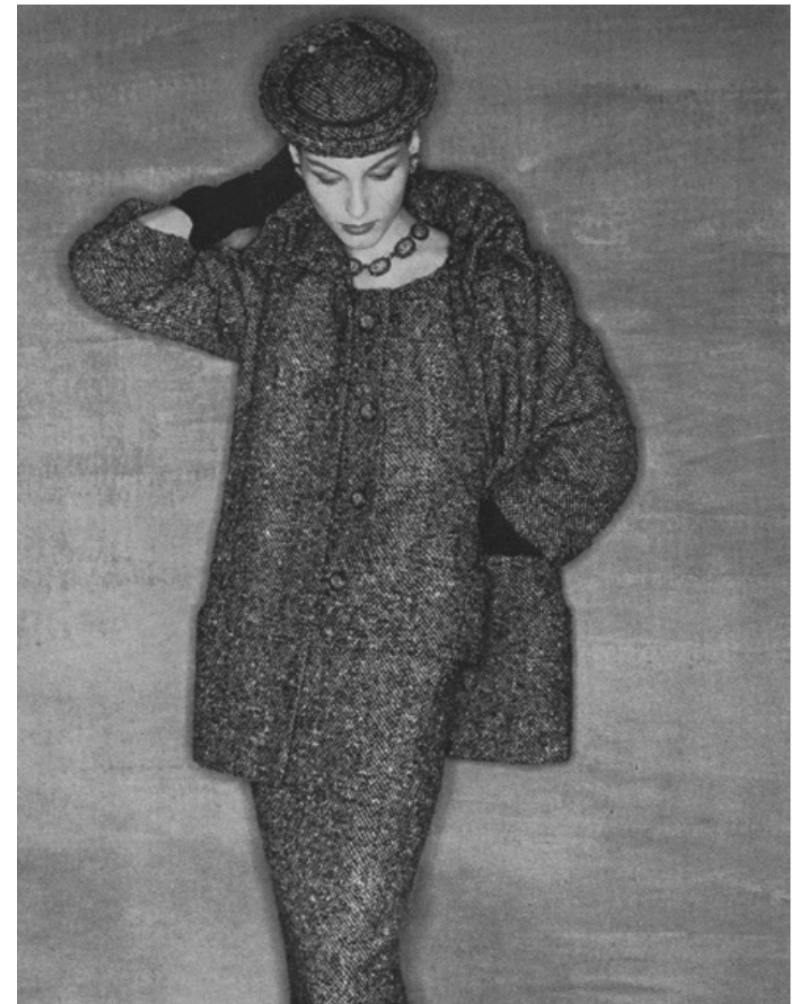

Figure 15: Christian Dior, Photographed by Clifford Coffin, Vogue, September 1954.

His sheathed bosom is actually an accessory to a new kind of femininity: subtler, not at all insistent, full of a charming reserve

ing to Napoleon-like fashion can say, "To look good, the clothes I wear must be chic, chic and once again chic". This goes like a red thread throughout Dior's entire creativity [7].

Very often, similar searches, which rely on the same source preserved in the past, influence fashion designers at different times, and if their work is not evaluated comprehensively and their merits are 
precisely fixed for a certain historical moment, we feel that direct loans may be made. For example, there is a Lahnwen dress that echoes elements of the nineteenth century, but similar elements are repeated at Poiret, and will probably be repeated in the future as soon as this kind of visual information becomes part of the fashionable social ideal [8].

Balenciaga also „discovers” many of the „innovations" that Dior claims to be his personal work during the 1947 collection, "The New Look". Balenciaga in this case may be cited as one of the "unofficial" innovators in the suit, but Dior outperforms it thanks to its powerful PR. That is why Balenciaga remains in the shadows while Dior becomes very popular.

\section{IMPLICATION OF SURREALISM INTO XXITH CENTURY FASHION - PRESENTED IN PICTURES}

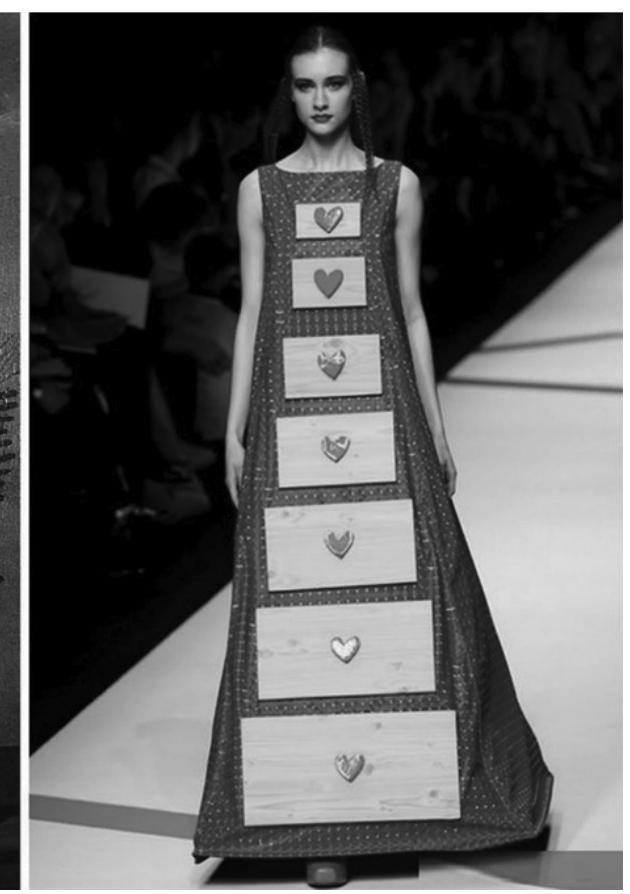

Figure 16: Salvador Dali “The Burning Giraffe", 1937 (left)

Model of designer Agatha Ruiz de la Prada Fall/Winter Collection 2009 (right)

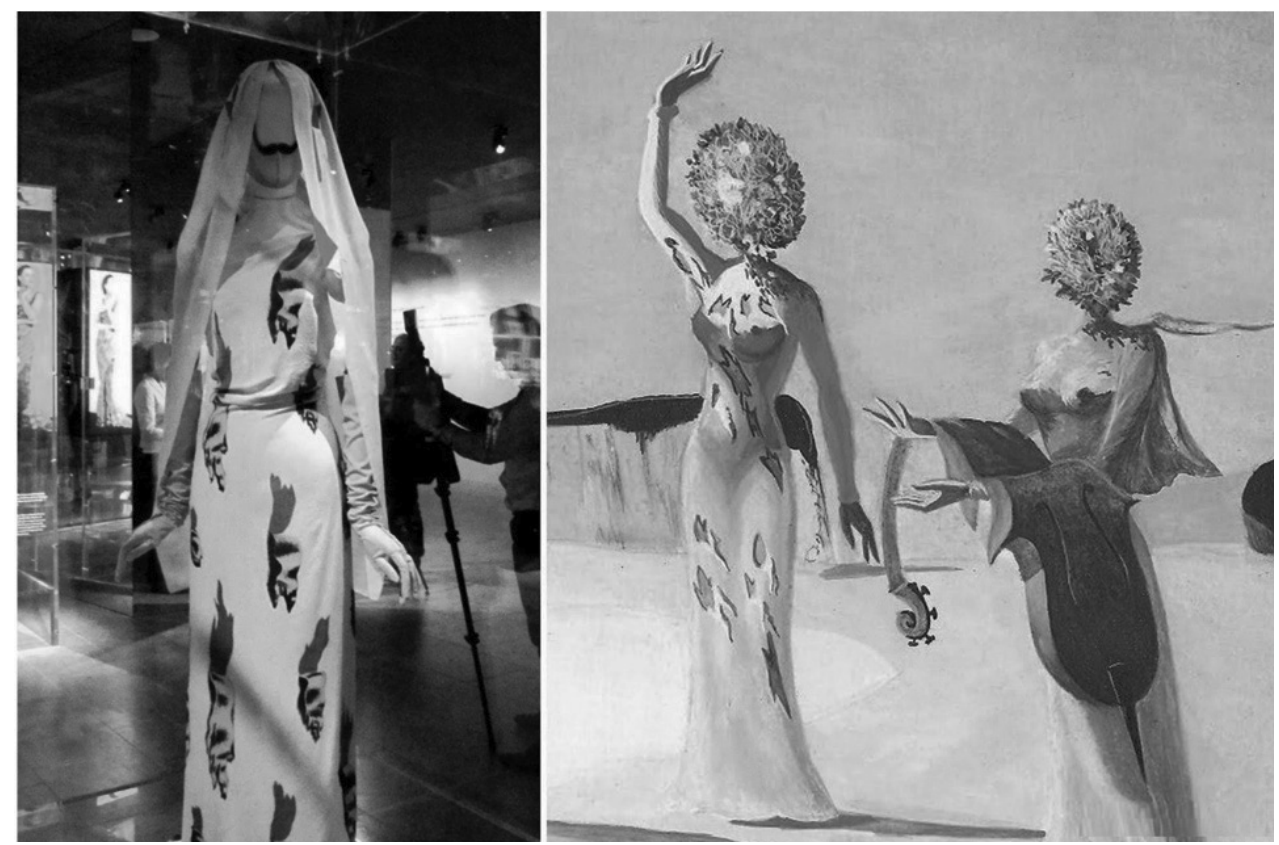

Figure 17: Model of Elsa Skiapareli from 1938 (left)

Salvador Dali "Three Young Surrealist Women Holding in Their Arms the Skins of an Orchestra" detail , 1936 (right) 


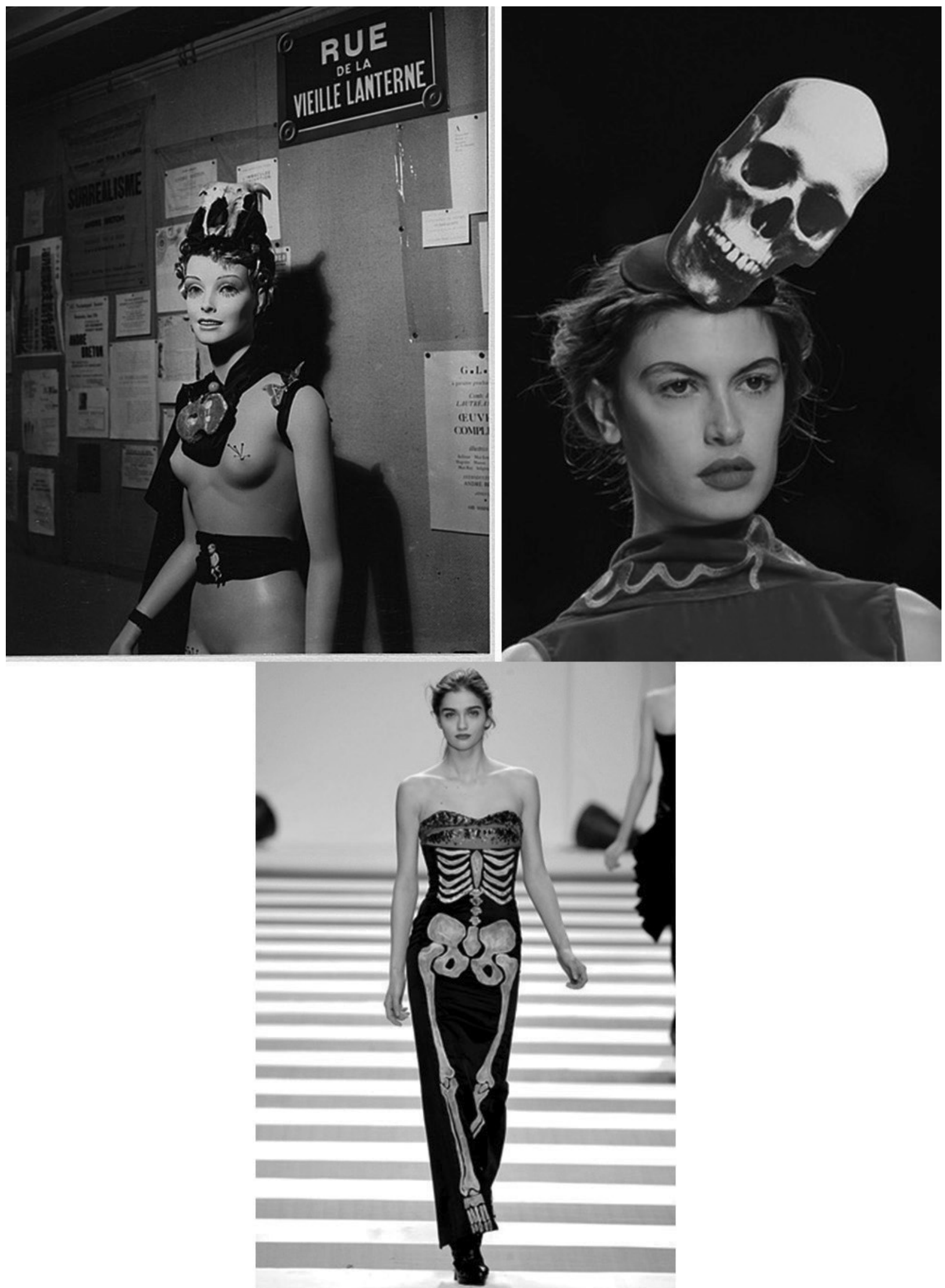

Figure 18: Man Ray: Mannequin with a skull on her head and a black belt around her waist) from Resurrection des Mannequins 1938-66 (above left) Jean Charles De Castelbajac collection (above right and down) 

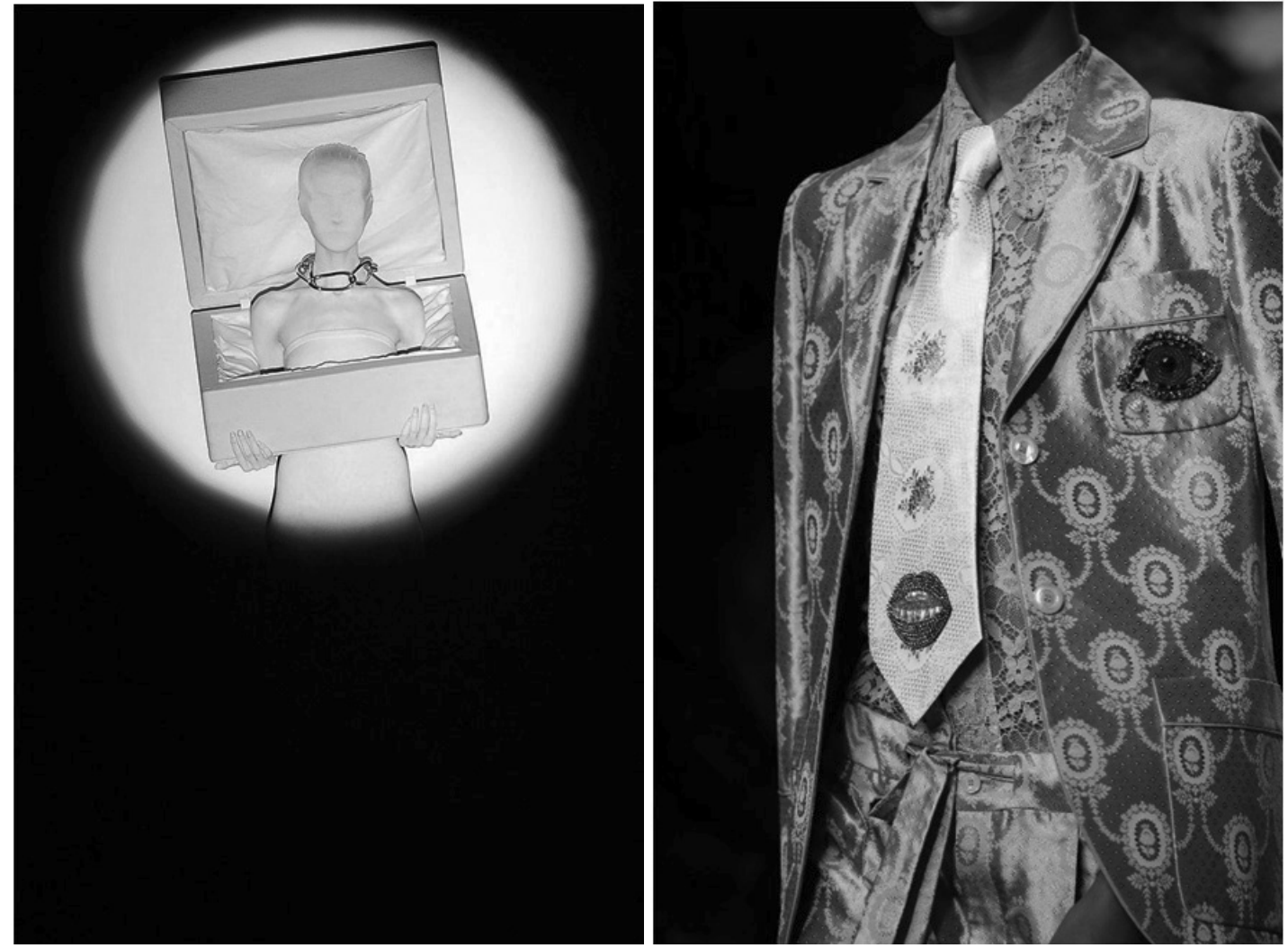

Figure 19: The ring's the thing; Maison Martin Margiela Spring 2009 (left) Alessandro Michele riffs on The Eye of Time, Gucci Spring 2016 (right)

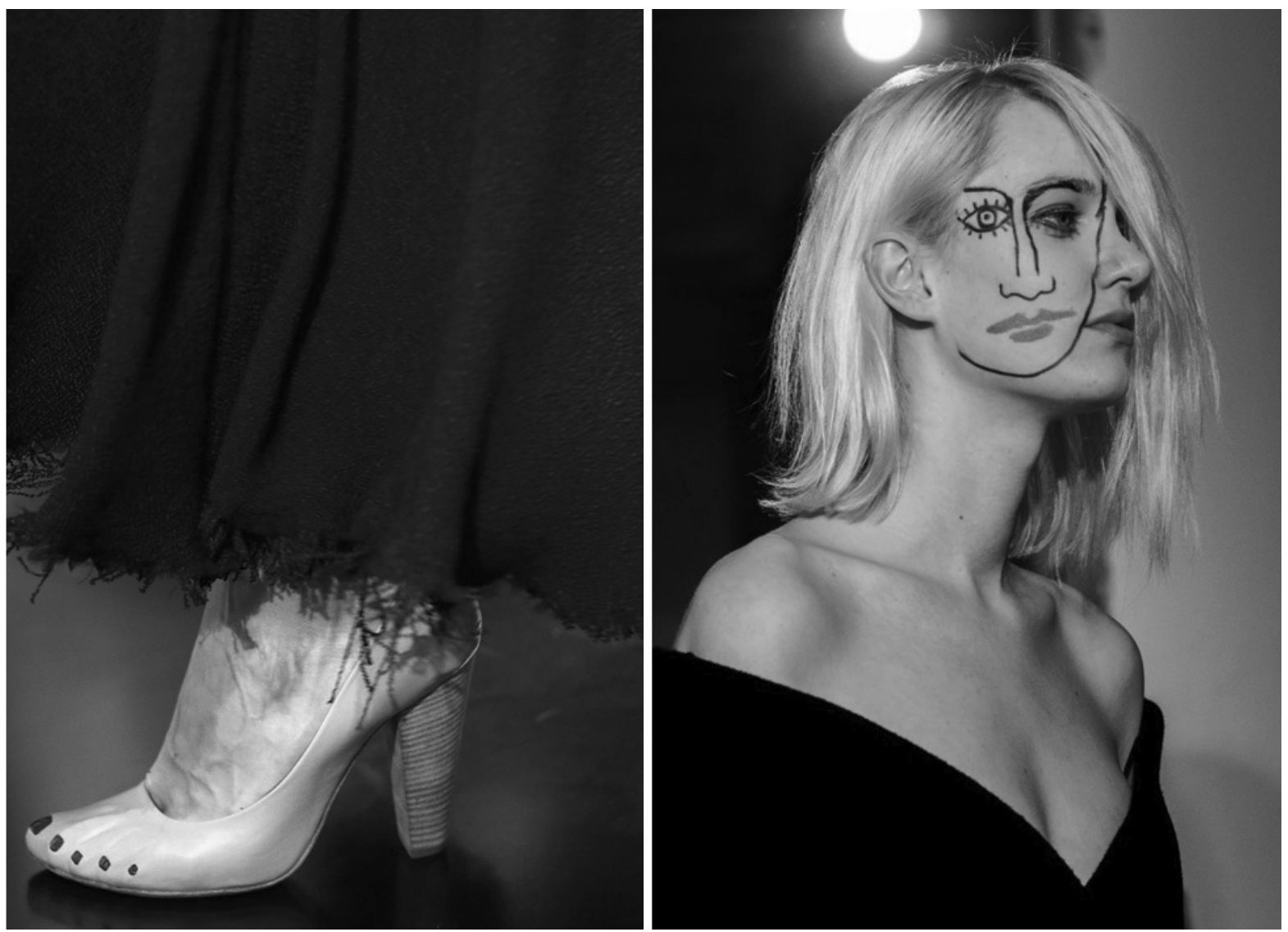

Figure 20: Peep-toes à la Céline Spring 2013 (left)

One of many two-faced beauties at Jacquemus Fall 2015 (right) 


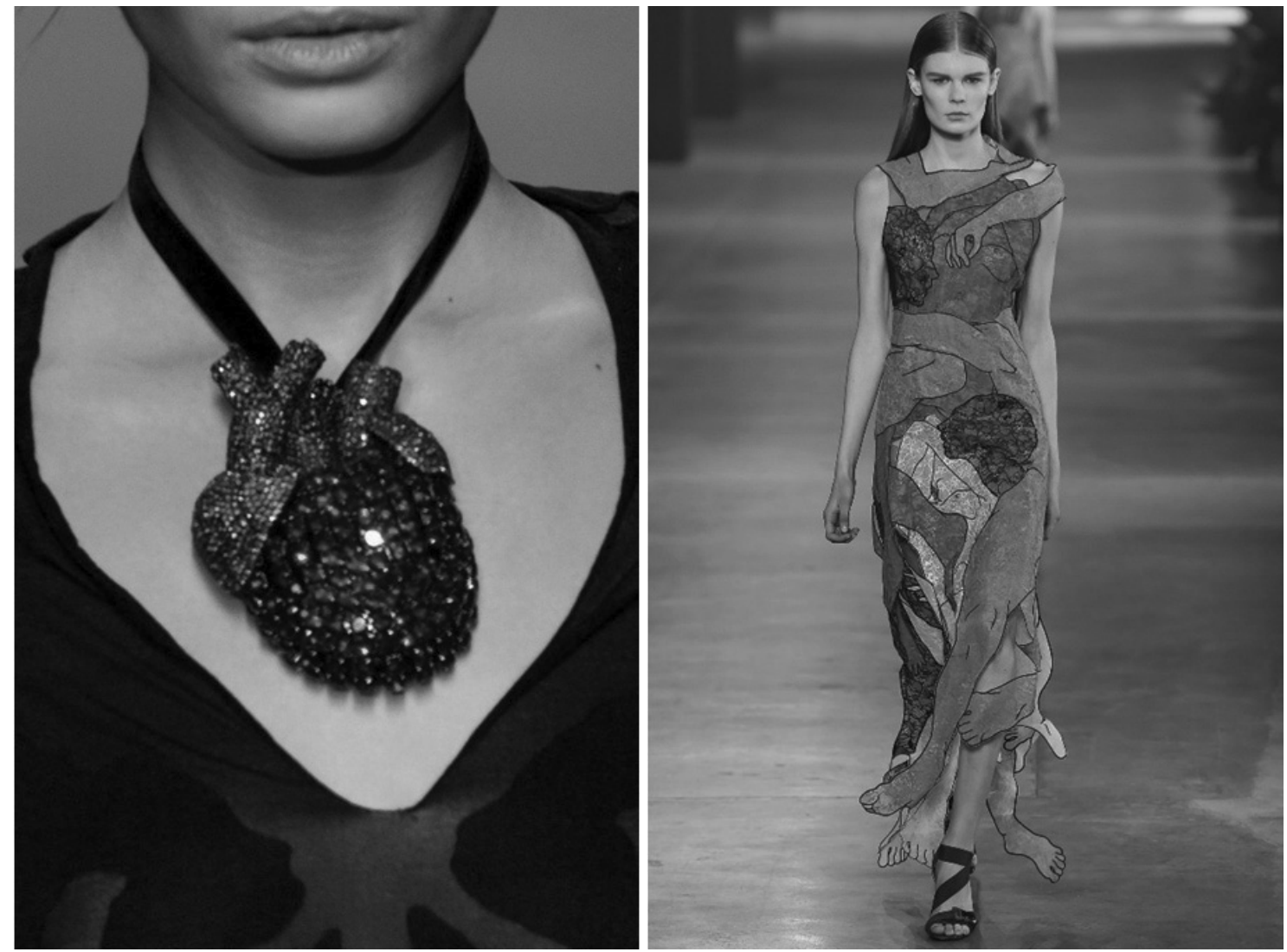

Figure 21: Heartfelt jewels from Yves Saint Laurent Spring 2003,

where Tom Ford took cues from Saint Laurent's pre-WWII yen for Surrealism (left)

Christopher Kane's Fall 2015 "lover's lace." (right)

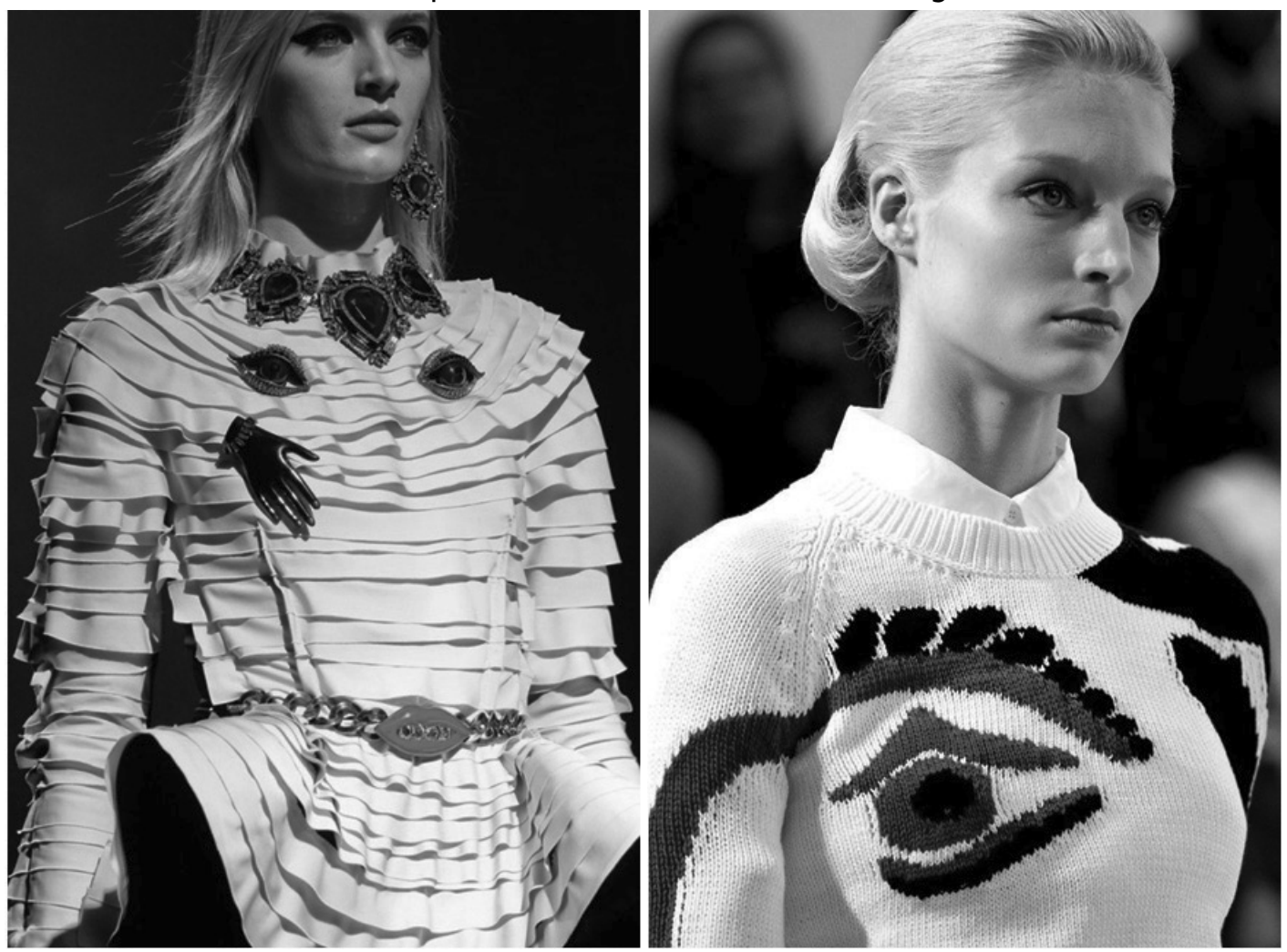

Figure 22: Bewitching baubles at Lanvin Fall 2012 (left)

While the inspiration for intarsias like this (Picasso) may not have been strictly Surrealist, Raf Simons struck upon the movement's spirit with his lineup for Jil Sander Spring 2012 (right) 

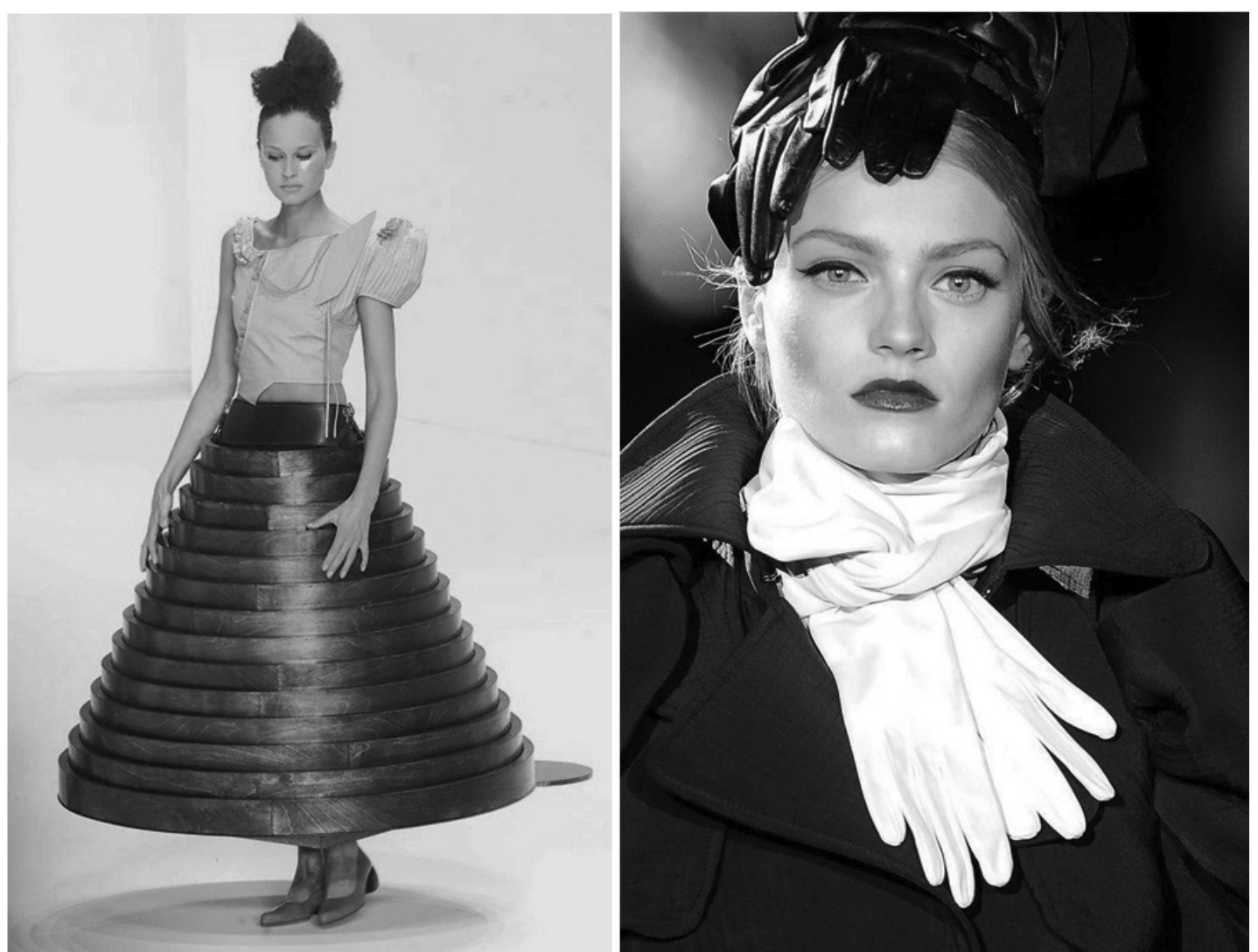

Figure 23: A performative piece from Chalayan Fall 2000-the show's closer stepped into a table on the set, and soon was wearing it as a skirt (left)

Dolce \& Gabbana's Fall 2009 offering was a direct homage to the famously surreal Elsa Schiaparelli (right)
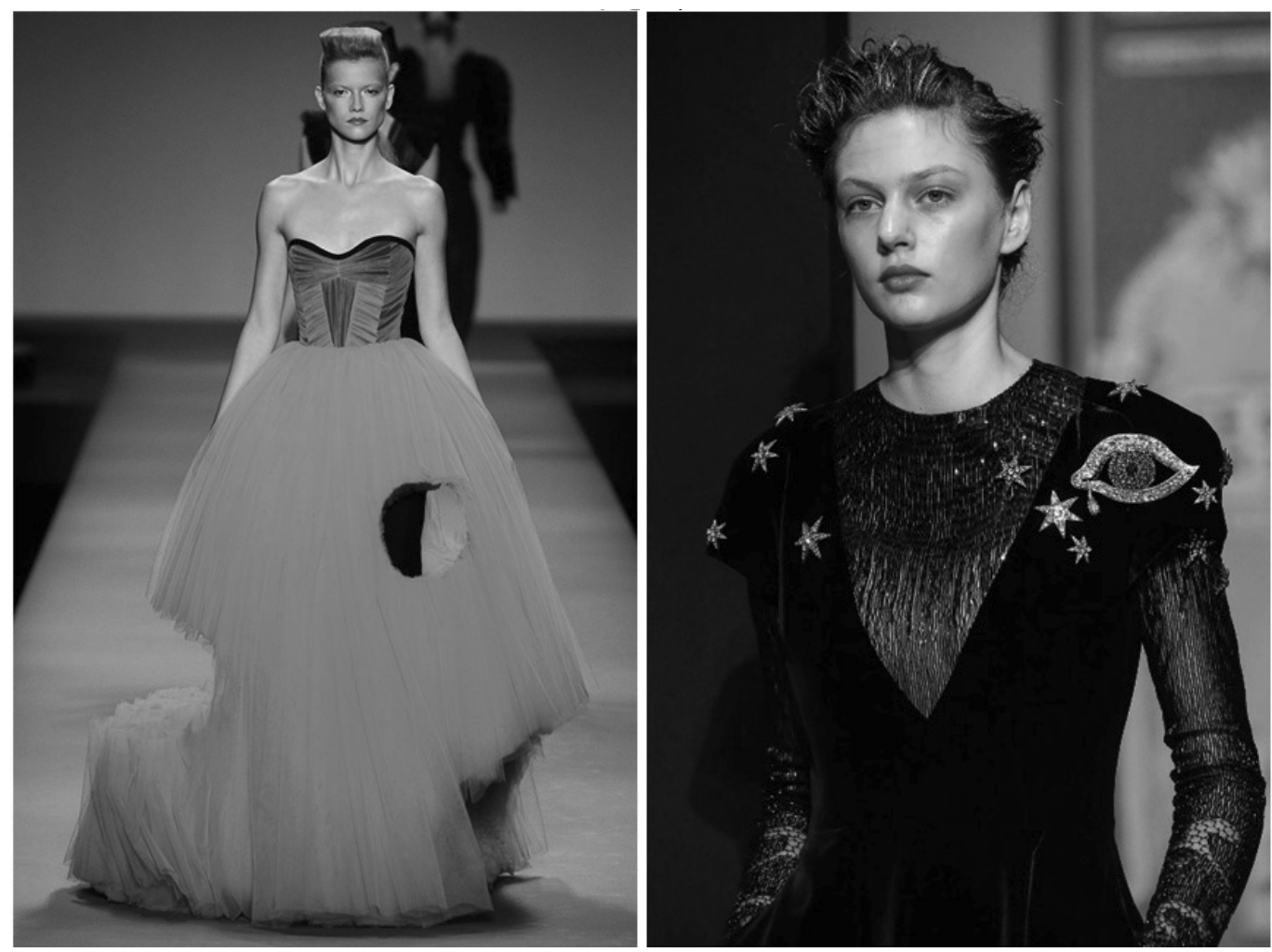

Figure 24: A hole lot of flair from Viktor \& Rolf Spring 2010 (left)

Dali's Eye of Time makes another cameo at the namesake house of his frequent collaborator: Schiaparelli Fall 2015 Couture (right) 


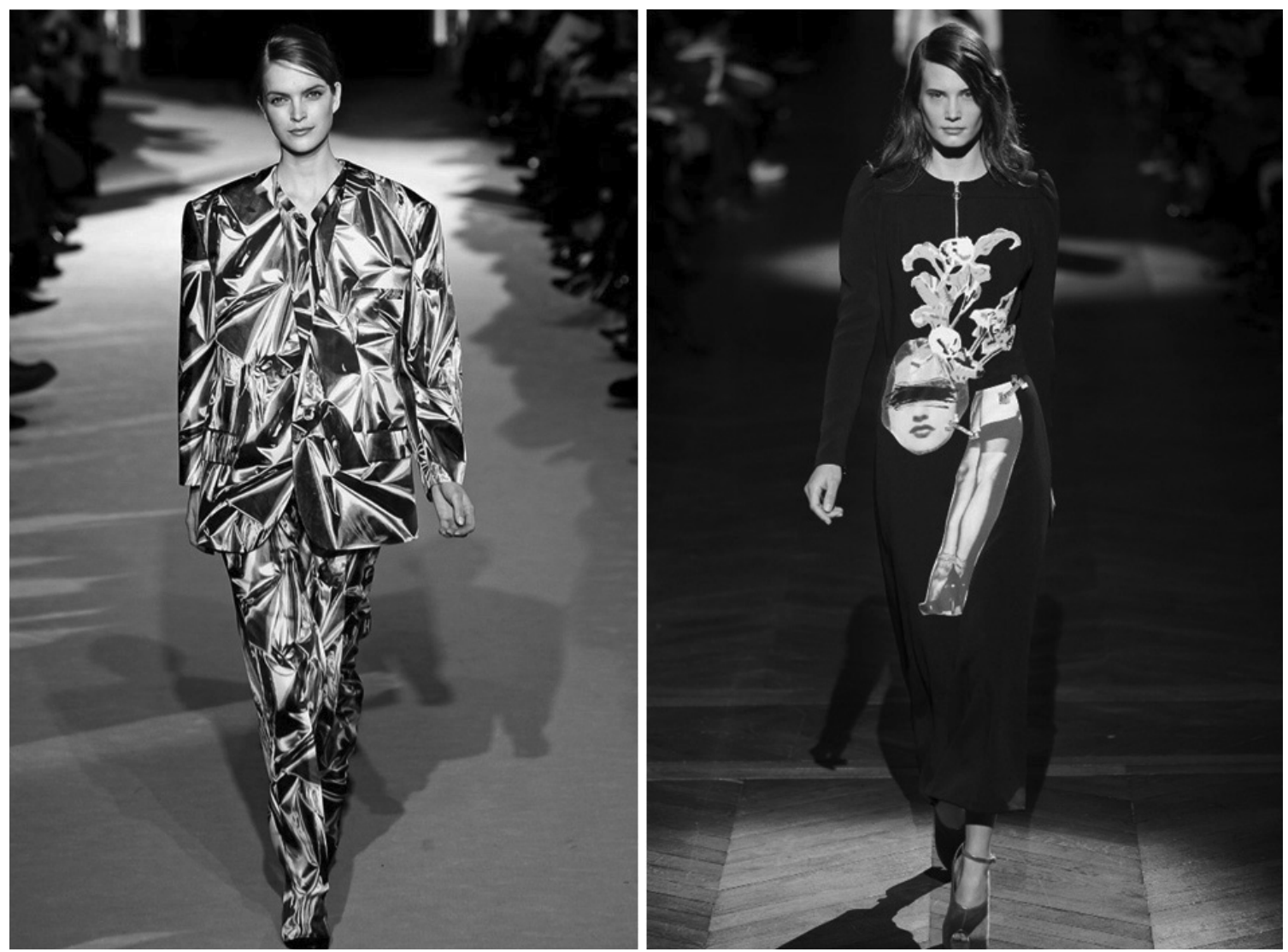

Figure 25: Stella McCartney's Fall 2011 trompe l'oeil Mylar suiting (left)

A Man Ray homage: Carven Fall 2014 (right)

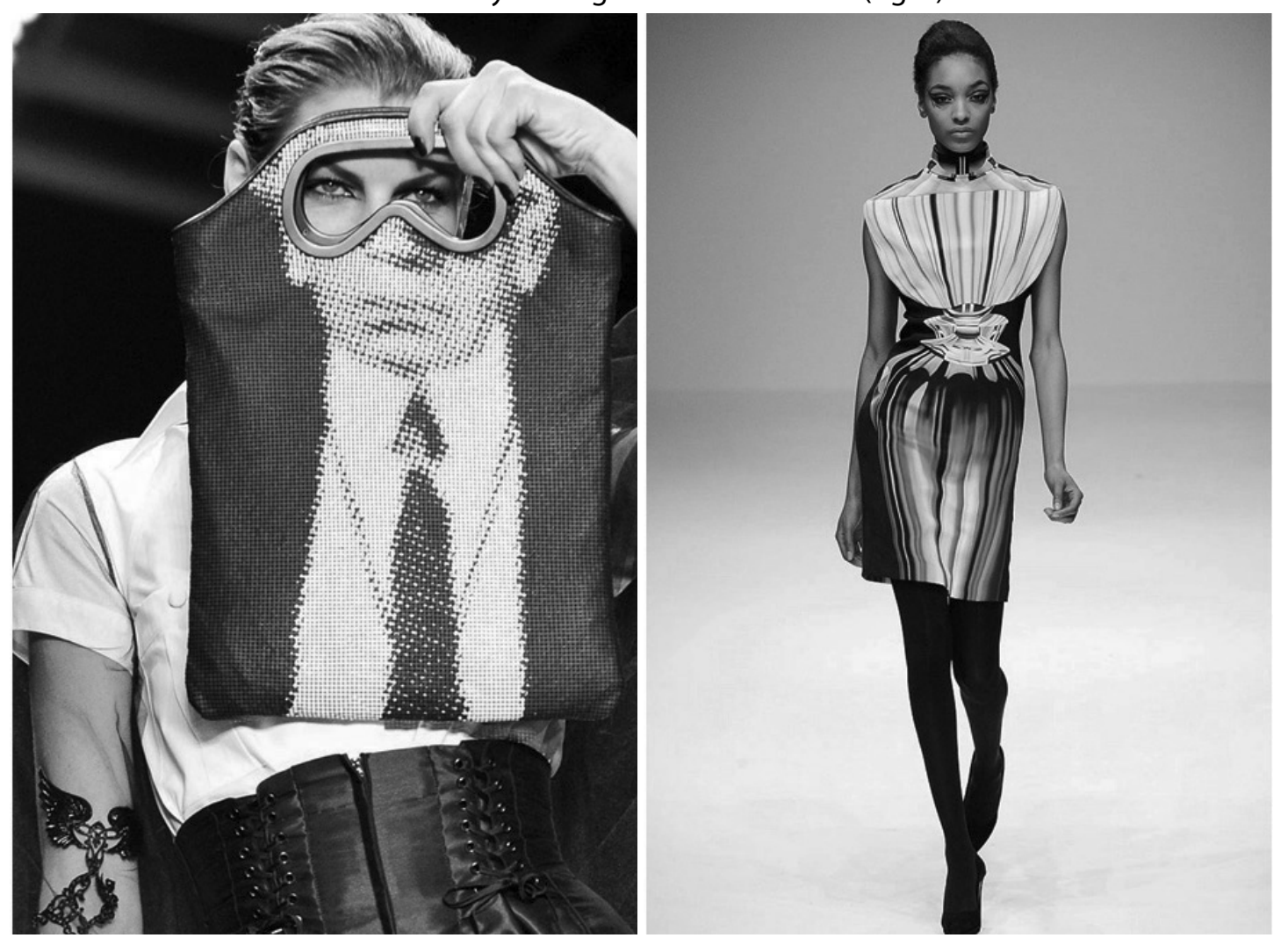

Figure 26: Karl, is that you? Angela Lindvall does her best Lagerfeld at the designer's eponymous Spring 2009 show (left)

Mary Katrantzou's Fall 2009 prints transformed her catwalks into sumptuous perfume bottles. 


\section{CONCLUSION}

In conclusion, thanks to the great historical inertia and good masters, as well as the conditions for creativity, art i.e. surrealism had a serious influence on the fashion of both modern and post-modern period.

The dilemma of line or volume, because there is no definitive once and for all established common solution, awaits the individual bright and memorable personal decisions that future designers will apply, relying on both the implication of art in fashion and the solutions proposed by their artistic predecessors.

The Surrealist impulse to tap the unconscious mind, and their interests in myth and primitivism, went on to shape many later movements, and the style remains influential to this today. Surrealism represents a crucible of avant-garde ideas and techniques that contemporary artists are still using today, including the introduction of chance elements into works of art.

\section{REFERENCES}

[1] Seе: „Мъдростта на вековете”, София.: „Наука и изкуство", 1970. - 573 с. Page 68 - Бирс, Амброаз Гвинет (Ambrose Gwinett Bierc, 1842-1914) American satirical writer and journalist

[2] Still there - page 68. Боаст, Пиер Клод Виктор (Pierre-Claude-Victore Boiste, 1765-1824) - French philosopher, lexicographer, author and collector of aphorisms

[3] Vecellio, C. Pegli abiti antichi e moderni di diverse parti del mondo... - Venetia: Presso Damian Zenaro, 1590

[4] Quote: „....одежде как таковой присущ несомненный эротизм, ведь она живет ожиданием тела своего хозяина или воспоминаниями о нем". See: Ольга Михайловская. Сюрреализм и мода. В Сб.Поэзия и критика. Вып.1. Весна 1994 г. Редактор Василий Кондратьев. СПб.: Изд.дом «Новая Луна», 1994. ISBN 5-85263-006-3 С.88-90.

[5] O`Hara, quotation p.72.

[6] Quote: „Женщина становится самой привлекательной к 35 годам, когда проходит ее первая молодость, расцветает её ум и она нуждается в шике" - Кристиан Диор. The quote was cited by electronic source: „Наталия Руденко Мир Диор (Dior) http:// www.womenclub.ru/fashonhistory/1377.htm

[7] Very characteristic in this respect are the models that can be seen on the following electronic sourc- es, with some Dior models noting only common markers from key elements of the 19th century, but also new ones:

http://www.beautifulcloth2u.com/wp-content/ uploads/2012/04/maria-luisa-black-silk-taffetagown-by-john-galliano-for-christian-diorelizabeth-period2.jpg

http://imagenes.tendenciasdemoda.com.ar/wpcontent/uploads/2011/10/christian_dior_03.jpg

http://imagenes.tendenciasdemoda.com.ar/wpcontent/uploads/2011/10/christian_dior_07.jpg

http://imagenes.tendenciasdemoda.com.ar/wpcontent/uploads/2011/10/christian_dior_05.jpg

http://imagenes.tendenciasdemoda.com.ar/wpcontent/uploads/2011/10/christian_dior_06.jpg

[8] For comparison, we will point to the image of a Lahnwen dress that I think has recurring 19th-century elements. http://i58.photobucket.com/albums/ g269/AlohaAroha/Textiles/Crafts\%20Deco\%20 Nouveau/M62.jpgThe original source is this page:

http://threadsofhistory.blogspot. com/2009_09_01_archive.html

The title below the photo is: Cyclone Dress, House of Lanvin (Jeanne Lanvin), 1939, silk, spangles Metropolitan Museum of Art.

\section{Bibliography:}

- $\quad$ Boucher, F., Deslandres, Y. (1987). 20,000 Years of Fashion: The History of Costume and Personal Adornment. Harry N. Abrams, New York.

- Барт, Р. (2005).Системата на модата. Агата-А, София.

- $\quad$ О) Хара, Д. (1995). Енциклопедия на модата. Библиотека 48, София.

- Martin, R. (1990). Fashion \& Surrealism. Rizzoli, New York.

- $\quad$ Baudot, F. (2002). Fashion \& Surrealism. Assouline Publishing, New York.

Rad primljen: 21.11.2019.

Rad prihvaćen: 11.12.2019. 